\title{
Pauline Theology and African Home: Exploring Cultures, Family and Faith in the Global South, Paul and Gender in Perspective
}

\author{
Rev. Fr. Dr. Anthony Amadi, C. S. Sp \\ Veritas Univeristy, Abuja. (The Catholic University of Nigeria).
}

\begin{abstract}
The main theme of this article is: "Pauline theology and African Home: Exploring Culture(s), Family, and faith in the Global South." In order to explore this theme fully, the article used historical research method because the researcher tried to know the meaning of events that happened in the life of Paul through systematic interpretations of time Paul lived and wrote as well as space. Time is necessary because every event is tied to the time in which it happened. The same applies to historical space because every event is tied to a specific space where it took place. Thus time and space are vital to our analysis and interpretation. The faith Paul preached and lived was dynamic and that appealed to Africans resulting to more adherents to Christianity as opposed to the global North. Extensive study was done on Pauline theology -analysing and interpreting factors that influenced his theology. In our enquiry of Paul and gender, it was discovered that humanity is one nature which subsists in two distinct modes namely male and female. Paul is aware of this fact especially when he addressed men and women in their cultural contexts. Our starting point here is Genesis 1:26-28. Our research on African family revealed that: 1) African families adapted to Pauline advice to the Colossians and the Ephesians, 2) Africa has a dynamic culture which permeates every fabric of the people. A typical African man knows and appreciates his culture. An African home is a place made up of children, parents and grandparents. African families do not send their aged parents and grand-parents to old peoples' homes because these aged ones are part and parcel of the family. This is another outstanding difference between and African family in the global South and the global North. The faith in Africa is getting rooted into the African culture. (299 words)
\end{abstract}

Key Words: Africa, Culture, Faith, Family, Gender, Paul, Theology.

\section{INTRODUCTION}

While the article focuses on "Pauline Theology and the African Home: Exploring Cultures, Family and Faith in the Global South," it also discusses Paul and gender in perspective. It must be clear from the start that this article centers on the global South with reference to Africa as opposed to the global North. This is because the African family for example, differs at least culturally from families in the northern hemisphere. Before we go into the main concern of this article, efforts would be made to say something on gender in general and then Paul and gender in particular. At the time when a child is born, the doctor or the nurse that assisted in the delivery of that child declares the child "a boy or a girl". It is a spontaneous observation confirmed by a declaration of a male or a female child. This declaration is facilitated by the 'external genitalia of the new born child.' The question those waiting outside ask is not about the health of the child, rather they would like to know whether the child is a boy or a girl. It follows therefore that the doctor on the spot is not only making an 'objective assessment of the newborn child, he/she is also performing a cultural act.' In other words, the society and culture play a significant role in forming the meaning of terms such as 'boy' or 'girl'. In other words, gender plays a significant role in understanding what it means to be human. That is, humanity is one nature that 'subsists in two distinct modes,' male and female.

The Genesis account 1:27 says:

"So God created man in his image; in the image of God He created him; male and female He created them. Immediately after this, God blessed them saying "Be fruitful and increase in number and fill the earth..." 
By this, humanity is made up of male and female. Illustrating this human embodiment with the incarnate Jesus, Cortez (2010, P.46) argues "... a theology that is informed by the incarnation and resurrection cannot afford to neglect the importance of human embodiment. Jesus did not come to us as the incarnation of an abstract human nature; he came as a sexual human being". We can say that this sexual nature of the human person connects to the mystery of being human.

Sachs (1991 p.48) summarizes this discussion in this comprehensive text:

Experience teaches that sexual, gender and role identity have always been shaped by powerful human forces, societal, cultural and religious. Today we are more aware of this fact. Realizing that these realities are, to some extent, our creations and not divinely established order, we must assume responsibilities for them, adopt a critical attitude towards them and seek to ensure that humanity male and female reflects the freedom, equality, dignity and mutuality which are divinely given and willed. In so doing, we must remember that no one has the authority to determine what it means to be a "manly" man or a "womanly" woman. Masculinity and femininity, important dimensions of our real, concrete ways of being human persons are precisely human, and therefore, part of a mysterious God-given realm of freedom, imagination and possibility.

The core of Sachs' argument finds meaning in this phrase 'seek to ensure that humanity male and female reflects the freedom, equality, dignity and mutuality which are divinely given and willed'.

This brings us to the next argument which centers on Paul and Gender. We prefer to treat this topic under Pauline theology since it is an important aspect of our discussion. In this article, we intend to discuss the following topics: Paul and his cultural background, Methodology, theology of Paul and Gender (male and female), Paul and family, family in general, Christian family, African family, and the impact of culture on African family

\section{PAUL AND HIS CULTURAL DIVERSITY}

This section introduces us to the person of Paul and to the culture into which he was born, on which he grew up and worked. The early information about the birth place of Paul was given by Paul himself in the Acts of the Apostles 22:3 where he said: "I am a Jew, born in Tarsus in Cilicia, but brought up here in the city (Jerusalem) where I was educated in the school of Gamaliel according to the strict observance of the law".

He was a Jew from Tarsus. Paul was born to a Jewish family but in a Hellenistic city of Asia Minor. As a son of a Pharisee, Paul was also a Pharisee. By birth, he became a Roman citizen. Appreciating the cultural diversity of Paul, Lucien (2001, p.113) comments: He preached and wrote in Greek and used the rhetorical resources of Greek literature, but he handled the rabbinic hermeneutic techniques with equal dexterity. At a glance, it becomes clear that Paul was a Hebrew, a Roman citizen and a Hellenist. The personality of Paul was unique characterized with three different worlds and three cultures: The Hebrew, Greek and the Roman (Kaitholil 2008). The cultural diversity, in which Paul found himself, influenced him remarkably. Kaitholil (2008, p.25) succinctly captures this cultural diversity of Paul in this comprehensive text:

The triple cultural dimension offered Paul the possibility of moving with confidence in totally different situations drawing from the riches of the Hebrew matrix in which he was born, to transplant them in Greco-Roman society. This is a delicate operation which today's church calls enculturation.

Though enculturation was not in vogue in the time of Paul, he was able to pre-empt enculturation through his personal contact and interaction with the surrounding cultures. 
Geertz (1973, p.3-4) is wise when he outlines the various concepts of culture as enunciated by Kluckhohn thus:

1. The total way of life of people

2. The social legacy the individual acquires from his people

3. A way of thinking and believing

4. An abstraction from behavior

5. A theory on the part of the anthropologist about the way in which a group of people in fact behave

6. A storehouse of pooled learning

7. A set of standardized orientation to recurrent problems

8. Learned behavior

9. A mechanism for the normative regulation of behavior

10. A set of techniques for adjusting both to the external environment and to other men

11. A precipitate of history: a turning, perhaps in desperation, to similes as a map, as a sieve, and as a matrix.

This encompassing definition is dynamic and life-enriching. Geertz (1973) is frank in his choice as he affirms; the concept of culture I espouse, and whose utility the essays below attempt to demonstrate is especially a semiotic one. Believing with Max Weber, that man is an animal suspended in the webs of significance he himself has spun, I take culture to be those webs, the analysis of it to be therefore not an experimental science in the search of law but an interpretative one in search of meaning. In every aspect of life, human beings continue to search for meaning as we try to understand the meaning of the name Paul.

Firstly, Paul was named after Saul, the first King of Israel given to them when they asked for a king. The Hebrew name (Saul) means "asked" (Onwukeme 2008). If Saul in the Old Testament means asked, that is the Israelites asked for a king, in the New Testament, Paul was asked by Jesus to be the apostles of the Gentiles. The Latin name "Paulus" according to Onwukeme (2008) means "small" "short". The argument therefore is if the Latin word Paul means small, the Hebrew name Saul which means asked defines his mission hence he was a great missionary. Considering the fact that he threw himself selflessly to the work of evangelism and preaching of the gospel, Paul indeed is a model for all missionaries. Paul not only travelled widely, he also wrote extensively as a preacher and as a theologian.

\section{METHODOLOGY OF THE WORK}

Basically, Paul's thought is historical as well as functional. A quick look at Galatians 4:4 -5 we hear Paul saying: "when the fullness of time came, God sent his son. He came born of a woman and subject to the law, in other to redeem the subjects of the law and to make us adopted children of God".

In this biblical passage, Paul understood the coming of Christ and the redemption of God in Christ all in historical terms. In line with Pauline thoughts therefore, the method that directs our discussion in this article is the historical method. In this section we explain what is meant by historical research method and highlight reasons for choosing it. The insight from Borg and Gall (1989) is helpful here when they see historical research method as the systematic search for fact relating to questions about the past and the interpretation of these facts. It follows therefore that the focus of historical research method is the meaning of events rather than the chronological listing of these events. The difference between historical research method and historical event is clear in the sense that; historical methods deal with meaning while historical narrative is concerned with the collection of major facts about historical events and putting them in chronological order.

The dynamism of historical event calls upon the historical researcher to be able not only to narrate what happened, rather to rationally explain why it happened and how it may affect the future event (Mhlargu, Naebe, 2003). This is where the crux of this article lies with respect to the method we have adopted. The narration of historical events is envisaged but the emphasis 
is on why it happened and how it will affect the future. The interpretative part of this method is of great importance. Mhlargu, Naebe (2003) affirm that historical research method consists of the collection, organization, verification, validation and analysis of information in accordance with specified standards.

This article intends to examine critically different sources related to our theme in order to verify, validate, their own authenticity and usefulness. In order to interpret events in their proper context, historically time is considered to be necessary because every event is tied to the time in which it happened. Equally important is historical space because every event is tied to a specific place where it took place. Having clarified these facts that are paramount to our methodology we now plume the theology of St. Paul.

\section{PAULINE THEOLOGY}

Indeed scholars acclaim Paul a great thinker and preacher. While McKenzie (1994) sees him as the most creative thinker in the history of Christianity, Kaitholil (2011) describes him as a convinced Pharisee who became a preacher of universal salvation. Just as scholars are highly interested in Pauline theology, so also does this article concerns itself on the thoughts of this great apostle - 'The Pauline theology.' In order to plume the theology of St. Paul, it is essential to emphasize that the Damascus experience should be central in determining the direction of Paul's thinking. Paul's theology is embedded in his writing which were not systematic because most of what Paul wrote was composed 'ad hoc' (Fitzmyer 1980) - for the handling of concrete situations by letters. Any attempt to discuss Pauline's theology should admit that Paul's thought is but one among several theologies in the New Testament. The faith of Christians in Christ is very central to Paul's theology. For Fitzmyer (1980) Paul's theology is an exposition of the inspired biblical heritage of Christians and to the Word of God proposed in his exposition still has an essential meaning for the faith of men (women) of today. Faith in Christ is dynamic that is why its expression in practical term attracts more adherents in the global South- Africa in particular than in the global North. Pauline letters composed 'ad hoc' to address on the spot emerging problems, appeal to Africans who resort to those letters in resolving their family problems. This explains why Paul's theology is part of normative biblical theology.

At this juncture, it is helpful to consider some important factors that influenced Paul's theology. We begin these factors with:

\section{Paul's Pharisaic and Rabbinical background.}

From time to time, Paul always looked back with pride on his life as a Jew of the pharisaic tradition, trained in Jerusalem (Phil 3:5-6, Gal 1:14). It is no wonder; therefore, that he thinks and expresses himself in the Old Testament images. This explains Paul's frequent use and reference to the Old Testament. However, like the rabbis, he at that time gives new meaning to the Old testament passages Rom 1:17, Hab2:4. As a result, his handling of the Old Testament is Rabbinical (Mckenzie 1994). In other words, his rabbinical training was a useful tool for him. It is worth noting that though Paul contrasts the "letter" (or the laws) and the "spirit" (Rom $2: 29 ; 7: 6-7,2$ Cor 3:6-7, the Old Testament is still for Paul a means through which God speaks to His people (1Cor 9:10, 2Cor 6:16, Rom 4:23)

\section{Hellenism}

In the first place, with his birth place in Tarsus and his training in Jerusalem presupposes the Hellenistic culture on his theology. By implication, it means that Aramaic was the language with which he was brought up and then learned Greek as his second language. The Greek Paul spoke and wrote was not the literary Koine. In effect, his Greek is full of Aramaising. Surely, evidence abound showing the influence of the Greek world even in his style of writing explicating that he knew Greek through the trainings in Greece.

Mckenzie (1994) maintaining a critical balanced position comments: "His Greek while not classic is easy band good; it is obscure only because of the packed density of his thought and his habit of proceeding to his conclusions by intuitive leaps rather than by measured steps". 
Fleming (1990) puts into proper context the two worlds of Paul and how they influenced him in these lines. The Greek influence on his education gave him the ability to think clearly band the Hebrew influence helped to create in him a character of moral uprightness (Phil 3:6).

\section{The Revelation of Paul}

Notably, Paul's theology was influenced by his experience on the road to Damascus and by the faith in the risen Christ- the Son of God. Paul proudly and confidently speaks on the Damascus experience as a personal revelation of the Son of God to him by the Father (Gal 1:16). In this revelation, Paul saw Jesus the Lord (1 Cor 9:1:15:8, 2Cor \$:6). Speaking authoritatively about the revelation, Fitzmyer (1980, p.803) declares:

That revelation of the crucified "Lord of Glory" (1cor 2:8) was the event that not only turned Paul the Pharisee into an apostle but also made him the first Christian theologian. The only difference between that experience in which Jesus appeared to him (1 Cor 15:8) and the experience of the official witnesses of the resurrection (acts1:22) was that his vision was post-Pentecostal. It puts him on an equal footing with the twelve who had seen the 'Kyrios'.

This revelation influenced Paul in three dimensions. Firstly, it made Paul to become very much aware of the importance of the unity of divine action for the salvation of all made manifest in both the New and the Old dispensations. Secondly, the revelation taught him the soteriological value of death and resurrection of Jesus the messiah. In other words, the revelation changed Paul's Christological theology. That is, there was a shift in his traditional theology where as a Jew, he shared the messianic expectations of his time. Thirdly, the revelation gave Paul a new vision of salvation history. Prior to his encounter with Christ the Lord, Paul believed that human history was divided into three phases:

a) From Adam to Moses

b) From Moses to the messiah (the period of the law)

c) The Messianic age (the period when the messiah would bring a new legislation).

Assessing the impact of this revelation on Paul, Fitzmyer (1980, p. 804) argues:

Far more than his pharisaic background, therefore or even his Hellenistic cultural roots, that revelation of Jesus gave Paul an ineffable insight into the "mystery of Christ". This enabled him to fashion his "gospel" to preach the fundamental good news in a form that was distinctively his own.

No wonder, therefore, Paul was very convinced when he claimed an apostleship of equal ranking with the other Apostles who saw the historical Jesus. The discussion now centers on his experience.

\section{Paul's Apostolic Experience}

The discussions on the factors that shaped Paul's theology would not be complete without a brief comment on his apostolic experience. In this experience he became a notable missionary who went round proclaiming the gospel and founding many churches. The saying, "experience is the best teacher" also applies to Paul because the problems he encountered in founding and governing individual local; churches were responsible for his gradual and personal awareness of the meaning of the church in a more universal sense.

We have said that Paul's theology is Christo-centric. For this reason, Paul frequently uses the expression 'in Christ Jesus'. In order to understand this expression of Paul, three principles are discussed:

i) God, in His love conceived and effected a plan of salvation for all in His Son through whom all things were made. Convinced of this, Paul taught that all creatures are bound to obey him since $\mathrm{He}$ is the redeemer (Col 1:15-20). This is the crux of the Christology in the letter to the Colossians.

ii) God gives people everything through Christ. Once again, convinced of this notion teaches that there is no salvation outside Christ. That is, it is in Christ that God justifies and predestines his 
people (Eph 1:4-5). God's grace to His people is made manifest in Christ (Tit 2:11). It is in Christ that God communicates his love to the effect that nothing can come between us and the love of Christ (Rom 8:39). It is in Christ also that we are reconciled to the Father hence we are entrusted with the message of reconciliation. (2 Cor 5:18-19).

iii) God gives through Christ and receives only what is united with Christ. Paul expressed this idea succinctly well in Ephesians 2:18 when he said "Through him we the people approach the Father in one spirit. For Christians; therefore, Kaitholil (2011) advises that there is only one objective, one ideal namely to be in communion with Christ and to participate in the life of Christ.

In the study of theology of Paul, certain ideas and virtues emerged and these are classified and discussed here. They are:

a) Paul and Gender- male and female

b) Paul and Faith

c) Paul and Family

\section{Paul and Gender- male and female}

This section examines Paul and gender. The first attempt focuses on the polemics about Paul's notion on women. The argument on gender borders on Genesis account chapter 1:26-28 where God said "Let us make man in our image to our likeness... so God created man in His Image, in the image of God He created him, Male and female he created them. God blessed them and said to them, be fruitful and multiply, fill the earth..." this biblical passage has generated a lot of argument in recent times. Authors have tried to define, explain or describe what gender is. One such definition and explanation adapted here is given by exploring theology: an introductory Dictionary:

Gender is a term that refers to the sexual roles and relationships that exist in the society. It is not synonymous to the biological category of 'sex' (male and female), because gender does not merely give attention to the biological factors. A gender approach looks at how identity, self-understanding and power relations develop (and are maintained) in the lives of women and men as they are socialized into the values of their culture. A gender studies approach is closely related to feminism but goes one step further since it also investigates the self-understanding of men in their relationship to women and other men (2004, p.29).

The emphasis on the above quotation is not specifically on the biological perspectives of gender but does not exclude it entirely. The emphasis is on what men and women have in common as sexual human beings created by God and not what differentiates them. Even where there is need to talk about the differences which are obvious, the ideal is to emphasize the complementary values of both sexes. Sachs (1991, p. 43) explains this beautifully in the context:

"The fact of sexual differentiation itself should remind us that no one, male or female, can ever claim to have plumed the depth of human existence. There is another mode of being human which is different from mine, perhaps radically different, and first as human. Any Christian anthropology should emphasize more on the dignity, freedom, equality and mutuality of men and women".

Our starting point is Genesis 1:26-28 where some authors have argued on the hierarchy between male and female. On the other hand, Sachs (1991) sees this hierarchy differently. For him, what is central is the human-divine hierarchy. His understanding of the human-divine hierarchy is that God shares a dominion with humanity male and female in order that they might actively image this dominion in and over creation. Further in the Genesis second account of creation, in chapter 2:22, the accounts says: "The rib which Yahweh God had taken from man he formed into a woman and brought her to the man". Some authors tend to interpret the idea of a helper to mean an inferiors status on the part of the woman. However, this is far-fetched because the helper here rightly stands for partnership in the creation. From the analysis and 
discussion it has become evident that humanity is one nature which subsists in two distinct modes, male and female. Each of these modes is fully human and relational. Both Cortez and Sachs agree that human sexuality is a mystery.

For Cortez (2010) the sexual nature of human person connects to the mystery of human in many ways. Sachs (1991) elaborates this mysterious aspect thus: masculinity and femininity, important dimensions of our real, concrete way of being human person, are precisely human and therefore, part of a mysterious God-given realm of freedom, imagination and possibility.

For one reason or the other, Paul has been accused of being unfriendly to the women-situation where he has been called anti-feminist or chauvinist. It is important to examine these accusations against Paul in the light of biblical context and culture.

In order to have a balanced discussion on Paul and women, it is necessary to have brief analysis of those biblical passages attributed to Paul- those passages that speak against women and those that speak in their favour. This discussion begins with Galatians 3:26-28. Here, Paul states :

"Now in Christ Jesus all of you are sons and daughters of God through faith. All of you through Baptism in Christ have put on Christ. There is no longer any difference between Jew and Greek or between slave and freedman or between man and woman: but all of you are one in Christ Jesus". Here, Paul recognizes the role baptism plays in the lives of followers of Christ. This is because, whether man or woman, older or younger, rich or poor, it is one baptism we all received, one faith to be professed and one God for all. Since baptism is the foundation on which other sacraments are built, it opens the way for all the baptized to be children of God without distinction. This is where I regard Witherup (2008) statement as very apt when he argues: 'distinctions according to race, social status, or gender are no longer the determining factors. Unity in Christ requires that we treat one another with human dignity and respect".

However, we must admit that Paul took a bold step to make such a statement in his time when the prevailing culture says the opposite. On the other hand, there are passages that anger women which on the surface justify the derogatory names given to Paul. These passages are from 1 Corinthians 14:34-35

"Let women be silent in the assemblies, as in all churches of the saints. They are not allowed to speak. Let them be submissive as the law commands. If there is anything they desire to know, let them consult their husbands at home..."

The other passage similar to the above is from 1 Timothy2:11-14

"Let a woman quietly receive instruction and be submissive. I permit no woman to teach or have authority over men. Let them be quiet. For Adam was created first and then Eve. Adam was not deceived; it was the woman who was deceived and fell into sin".

At a glance 1 Corinthians 14:34-35 appears as a contradiction of what Paul said earlier in Galatians 3:26-28. Scholars continue to ask why such a radical change of mind? Other scholars trying to find a solution tend to suggest that 'Paul modified his egalitarian view of the genders because resistance from various sectors of the predominantly patriarchal culture proved to be a block to the proclamation of the gospel'. (Dianzon 2007:67).

In support of Dianzon, Kaitholil (2008) "Paul[s vision on women was culturally conditioned. On his part, Witherup (2008), Paul was a man of his day, and he lived in a society that basically considered women as inferior to men. An explanation for the other passages that seem to relegate women to a subordinate position 1 Tim 2:11-14, Eph 5:22 and Col 13:18 are equally plausible in the sense that these three passages were not written by Paul himself with his own hands. These are letters written by Paul's disciples but attributed to him.

After a critical look on these bible passages, it is not completely correct to judge Paul with the $21^{\text {st }}$ century parameter. The children with technological knowhow laugh at their grandparents who did not use mobile phones and computers. If such situations exist even now where the generation gap is not too wide to remember - 19th Century to $21^{\text {st }}$ Century, then there is need 
to ask this important question: What right then do we in the $21^{\text {st }}$ century have to judge Paul who lived as far back as $1^{\text {st }}$ century AD probably between AD 5 and 10? (Kizhakkeyil 2011). Dunn (2006) echoes this sentiment thus: only with the letter of Paul can we fully be confident that we are in touch with the first generation of Christianity.

I tend to conclude this discussion on Paul and gender agreeing with Dianzon (2007) who affirms: "We can thus safely say that the original Paul is far from a chauvinist and anti-feminist. He was in fact, a champion of eschatological egalitarianism. In spite of the criticisms, we still see in Paul a man of faith".

\section{Paul and Faith}

Fleming (1990) lays a solid background for the understanding of faith in a language that is rooted in the bible. Expressly Fleming (1990) states:

In the original language of the New Testament, the noun 'faith' and the verb 'believe' are different parts of the same word. Although faith involves belief, by far the most important characteristic of faith (in the biblical sense) is reliance or trust (1999, p.127)

The Catechism of the Catholic Church number 143 describes faith thus: "By faith, man completely submits his intellect and his will to God. With his whole being man gives his absent to God the revealer. Sacred scripture calls this human response to God, the author of revelation, 'the obedience of faith'. With this beautiful background laid let us examine how Paul conceived faith and how this faith is manifested in his life. Lapide (2008) has a beautiful way of describing Paul's faith when he affirms: Paul excelled in faith. In fact as a doctor, he preached it everywhere and defended it against the dissenting Jews, philosophers, orators, magicians, kings and tyrants. This description is true because in the life of Paul every attempt was made by his fellow Jews to silence the faith in Paul, the more strengthened he was to preach the gospel more loudly everywhere. That is why the expression 'to be in Christ' is deeply rooted in Paul. Being rooted in Christ, Paul wants to express a union which is personal, a reciprocal communion and organic relationship. It is a union of love which is the result of our incorporation in Christ (Kaitholil 2011). One of the letters where Paul came out strongly about his conviction or faith is Romans $1: 16-17$ when he proclaims: "For I am not ashamed at all of this Good news ; it is God's power saving those who believe, first the Jews and then the Gentiles. This good news shows us how God makes people upright through faith for the life of faith, as the scripture says: the upright one by faith shall live"

In Romans 3:27-31, Paul teaches that justification is by faith. Some scholars argue that justification is central in Pauline theology. Capitalizing on Romans 3:28, Martin Luther interpreted the text to mean that a person is justified by faith only- "sola fide".

Justification therefore is God's great act of salvation by which he declares the repentant sinner righteous before Him. Justification is the most excellent work of God's mercy (CCC 2023).

In 1 Corinthians, Paul recalls the three import virtues- Faith, Hope and Love but Paul singles out Love as the greatest. Faith for Paul is primarily a personal relationship with God and with Jesus Christ. Faith therefore is free obedience to Christ and being configured to his life (Witherup 2008). After going through the teachings of Paul his teachings and preaching the difficulties and sufferings he encountered during his missionary journeys, it was evident that Paul by these heroic deeds manifested to the world his great faith.

\section{Paul and Family}

Going back to God's plan for humanity and human life specifically, people do not exist in isolation. While they are bonded as part of a vast society, they are fitted in the society where they are brought up as families. Paul recognizes that it is through God the Father that families have their existence. There was no biblical evidence that Paul married to nurture a nuclear family, whatever he taught about faith, love and every other Christian virtue found itself in the family which is the basic unit of society. For the society to be sustained and families built up, 
Paul had great respect for marriage which he elevated highly. In Ephesians 5:31-32, Paul comments: "Scripture says: because of this a man shall leave his father and his mother and be united with his wife and the two shall become one flesh. This is a very great mystery and I refer to Christ and his Church.". This shows that Paul has great respect for the loving union of man and woman in holy matrimony. The mystery Paul talked about here is the divine plan of salvation in Christ explicated in Ephesians 3:3-6. Another dimension of this mystery is the intimate and indissoluble relationship between Christ and his church. For Paul, the moment the husband and the wife love and cherish each other in the way and manner Christ loves and cherishes his church; there will be faithfulness which in turn produces Christian families. Paul's advice on obedience in Colossians 3:18-21 is such that builds and sustains families. "Wives submit to your husbands as you should to the Lord. Husbands love your wives and do not get angry with them. Children obey your parents in everything because that pleases the Lord".

The submission Paul talks about here should be done out of reverence for Christ and not out of fear. It is a submission out of love because love expels fear. So Paul advocates for peaceful families.

\section{Christian Families}

Before we discuss African families, it is expedient to examine Christian family especially in the global South. Tracing the family to the creator of the universe, the second Vatican Council under the decree of the Apostolic of the Laity No. 11 declares: "Since the creator of all things has established the conjugal partnership as the beginning and basis of human society, the family is the first and vital cell of society". The family has a very important role to play in the development of individuals who make up the society. Recognizing this important role of the family, Pope John Paul II (1982, p.55) comments:

The family has vital and organic links with the society. Since it is its foundation and nourishes it continually, through its role of service to life, it is within the family that they find the first school of the social virtues that are the animating principle of the existence and development of the society itself. Thus far from being closed in on itself, the family is by nature and vocation open to other families and to society and undertakes its social role.

These two quotations from the Vatican II and the Pope John Paul II have given us the essential elements that make up a family. The quotations have rightly pointed the origin of the family to God the creator who uses the man and the woman (parents) to bring forth the life on earth thereby situating the family into the society- the larger streamline organ. Being open to other families in the society, Christian families have religious, spiritual, civic and social roles to perform. In the first place, Christian families are called upon to offer everyone a witness of generous and disinterested dedication to social matters through a "preferential option for the poor and disadvantaged. Christian families are expected to evangelize to the world with the gospel of Christ proclaimed by the word of the mouth but especially in their lifestyles. Beginning from among themselves in various families, the parents not only communicate the gospel to their children but from their children they can themselves receive the same gospel as deeply lived by them. In a society that is turning to materialism and secularism, Christian families have a special vocation to witness to the paschal covenant of Christ by constantly radiating the joy of love and the certainty of the hope for which they must give an account. Pope John Paul II captures this sentiment in these lines: in places where wide-spread unbelief or invasive secularism makes real religious growth particularly impossible, 'the school of the home' remains the one place where children and young people receive an authentic catechesis (1982). Individual family members are challenged to be solidly grounded in their faith so that they will touch the society around them and beyond their lives.

It has been stated and here we re-emphasize it that family is the vital cell of the society. Christian families need to be transformed by the Holy Spirit to enable them transform the 
society. Therefore Christian families need to offer themselves to the glory of God and also through a life of prayer, through prayerful dialogue with the Father through Jesus Christ in the Holy Spirit. In other words, the dignity and responsibility of the Christian family as a domestic church can be achieved only with God's unceasing help which surely will be granted if it is humbly and trustingly petitioned in prayer. At this juncture, it is important to help Christian families know some of the rights proposed by the synod of 1980 on family. Among others, the synod fatted stated the following rights of the family:

i) The right to exist and progress as a family, that is to say the right of every human being even if he or she is poor, to found a family and to have adequate means to support it.

ii) The right to exercise its responsibility regarding the transmission of life and to educate children.

iii) The right to the intimacy of conjugal and family life;

iv) The right to the stability of the bond and of the institution of marriage.

v) The right to believe in and profess one's faith and to propagate it.

vi) The right to bring up children in accordance with the family's own traditions and religious and cultural values with the necessary instruments, means and institutions;

vii) The right, especially of the poor and the sick, to obtain physical, social, political and economic security.

viii) The right to expression and to representation, either directly or through associations, before the economic, social and cultural, public authorities and lower authorities;

ix) The right to protect minors by adequate institutions from harmful drugs, pornography, alcoholism etc

x) The right of the elderly to a worthy life and a worthy death (1982, p. 58).

The last two rights deserve some comments. The Christian families are challenged now than ever before to protect the minors from many dangers which glaringly are attractive to these young ones. The abuse of minors has become rampant, the addiction to drugs and alcoholism is very devastating and the use of human parts for rituals is deadly. Aware that human families have been disunited by sin; therefore, the family should take recourse to the redemptive power of the death and resurrection of Christ. Finally, the right of the elderly to a worthy life and a worthy death as a prelude where we shall show that elders are full members of the African families who are taken care of by all the family members.

\section{African Family}

The African family is the second major segment of this article which will bring our investigation to its conclusion. This statement by Mwaura (2005) is very apt in the introduction of this section when she argues: "Africa is one of the continents where Christianity has experienced rapid growth to the extent that scholars agree that the Christian centre of gravity has shifted from North to South". This statement is not only factual, it is buttressing to our topic. This section examines African family in the light of Pauline theology using African cultures as good sources of enriching Christian faith as exemplified in the global South.

Among the facets that will help us discuss African family, culture is one which needs to be explored to see how it enriches Christian faith in Africa. Culture is an aspect of what it means to be human, and therefore a basic human right. Shorter (1998) gives a descriptive explanation of culture in this text: Culture is the whole way of life, material and non-material of a human society. It is essentially social, the product of the society's tradition and its interact5ion with other societies. Culture is dynamic, not a static phenomenon. It is also the product of human history".

In his Post-Synodal Apostolic exhortation Ecclesia in Africa, Pope John Paul II (1995, p.33-34) gives a comprehensive view of African family in the African culture.

In African culture and tradition, the role of the family is everywhere held to be fundamental. Open to the sense of the family, of love and respect for life, the African loves children who are joyfully welcomed as gifts of God. The sons and the daughters of Africa love life. It is precisely this love for life that leads them to give great importance to the veneration of their ancestors. 
They believe intuitively that the dead continue to live and remain in communion with them. Is this not in some way a preparation for belief in the communion on the saints? ... Africans show respect to human life until its natural end, and keep elderly parents and relatives within the family.

I think the late Pope saw certain important things in African family which are different from European family which impressed him and which prompted him to make these laudable comments. In his letter to the Colossians, Paul gave advice on how parents and their children ought to live in a home characterized by peace, love, respect, obedience and service. This is exactly what Pope John Paul II saw in the African family and which he highly commended. What follows now is a discussion on how African families put into practice the advice Paul gave to the Colossians.

In his Post-Synodal Apostolic Exhortation Africa Munus, Pope Benedict XVI situates African family in the 'global South' in this refined expression.

The family is the sanctuary of life and a vital cell of society and of the church. It is here that the features of a people take shape; it is here that its members acquire basic teachings. They learn to love in as much as they are unconditionally loved, they learn to love in as much as they are respected, they learn respect for others in as much as they are respected, they learn the face of God in as much as they receive a first revelation of it from a father and a mother full of attention in their regard (2011, p.26-27).

These are the basic ingredients that build up a good Christian family and they are evidenced in the African families. In this respect, everyone is fully aware that the family is where members acquire basic teachings, learn to love and to be loved, to respect and be respected, learn to know and obey God then everyone aims to hold the fancily in a high esteem and tries to work for its success.

Appreciating the roles individuals play in African families, Pope Benedict XVI acknowledges among all the roles the elders play. This is what he says of elders.

In Africa, stability and social order are still entrusted to a council of elders or traditional chiefs. Through this structure, the elderly can contribute effectively to the building of a more just society which evolves, not on the basis of whatever experiences happen to come its way, but gradually and with a prudent equilibrium. The elderly are thus able to participate in the reconciliation of individuals and communities through their wisdom and experience.

Indeed, elders are real treasures that any reasonable person would like to have. With their wisdom and experience, they bring reconciliation, they bring unity and togetherness. They are indeed useful to their families and to the society. No wonder, therefore, that African culture permits that the aged grandparents should be kept and looked after in the families till their death because they are still full members of their families. A typical African family that knows its culture well appreciates the aged parents and grandparents and does not send them to old people's homes. An African home is a place made up of children, parents and grandparents. This is a great difference between African families and Western families.

The men regarded as the fathers of the house have noble responsibilities of exercising their God-given role of raising their children and bringing them up in the presence of God. They provide for their children in all aspects of life: intellectual, physical and spiritual. They lead by good examples. Trustworthy African fathers are very conscious of Paul's exhortation in Ephesians 3:17 to love their wives as Christ loved the church and gave himself up for her. African Christian fathers give themselves and all that they have in order to sustain their families. However, some men have not lived up to these expectations.

\section{WOMEN IN THE AFRICAN FAMILY AND CHURCH}

Some critiques see African culture as too oppressive to women to the extent that they have no good comment for it. Judging African Culture from the perspective of "woman and child bearing" Magesa (2010 p.94) documents: 
Woman has been deprived in the African culture predominantly from the physical perspective, and then largely in terms of her biological functions of motherhood. But is it acceptable that a person's entire being be understood on the basis of one aspect of life alone however important to humanity that aspect may be? Restricting woman's personality and personhood exclusively to motherhood has brought about serious gender imbalances and women marginalization in Africa. The woman is seen practically to have no value apart from motherhood: therefore she can be married off at a very young age; she should not receive a befitting burial if she dies without children..."

Magesa highlighted an unimportant truth however, he over stressed it to the exclusion of other related facts that give credit to women. In her own balanced observation, Wakahiu (2015) articulates:

It was typical that the role a woman played was that of an educator, transmitting knowledge and morals and introducing her children to the norms of the community. As a mother, her role was fundamental for the biological, physical, psychological, moral, social and religious maturation of her children. Wirba (2012) posits that a woman was perceived as a counselor and an influential adviser to the husband, but was to remain silent and distinct in public arena.

Reflecting on the same African culture, these two authors- Magesa and Wakahiu have different observations and comments. Obviously, Wakahiu's comments from a female perspective are more encompassing and more balanced.

Acknowledging the role of women in the African family, Pope Benedict XVI adds his own voice to that of St. John Paul II by saying: "Women in Africa make a great contribution to the family, to society and to the church by their many talents and unique gifts. As John Paul II said " Woman is one in whom the order of love in the created world of person takes first root. The church and society need women to take their full place in the world so that the human race can live in the world without completely losing its humanity" (2011 p. 31). The Pope started with the positive comment then went to the other side of African culture that needs improvement as he declared:

While it is undeniable that in certain African countries progress has been made towards the advancement of women and their education, it remains the case that; overall, women's dignity and rights as well as their essential contribution to the family and society have not been fully acknowledged or appreciated. These women and girls are often afforded fewer opportunities than men and boys. There are still many practices that debase and degrade women in the name of ancestral tradition (2011 p.31).

Surely such debasing ancestral traditions and cultures should be modified to make them reflect the realities of the 21st century world view.

Certainly there are some good aspects of African cultures that are helpful for evangelization. Such cultures are encouraged, transformed and adapted into Christian faith. However those that have negative connotations should be abolished.

In our discussion on African family and culture, it has been discovered that Africans themselves have different perceptions about their culture. Consequently their comments on African family and culture reflect these perceptions. In the same way, Paul's reaction towards women differed from place to place. In his missionary journeys, Paul worked with some women and he acknowledged them by mentioning their names.

Few of these women to be mentioned here are: Lydia whom Paul described as "God fearing woman" (Acts 16:14). The Bible mentioned a couple together whenever their association with Paul was discussed but most often, Paul mentioned Prisca/Priscilla first before her husband Aquila. In Acts 18:18 we read: "Paul stayed on with the brothers in Corinth for many days. He then left them and sailed off with Priscilla and Aquila for Syria". In his own words, Paul said: " 
Greetings to Prisca and Aquila my helpers in Christ Jesus" (Roman 16:3). Though Paul disapproved the disagreement between Evodia and Syntych, he acknowledged that both women laboured with him in the service of the gospel of the Lord (Phil 4:2-3). In a very special way, Paul identified Phoebe as Deaconess and then recommended that she be helped in her work since she helped many others including him (Rom 16:1).

The fact that Paul was able to work with some women and also commended them highly showed that he was not anti-women, instead he could be called a model of cooperative ministry.

\section{CONCLUSION}

Paul, the great apostle of the Gentile, was a great missionary and a seasoned theologian who contributed immensely to the spread of Christianity through his many letters to the various churches he founded. In spite of this, some people accused him of being 'anti-women' because of some pronouncements he made based on cultural circumstances. However, Paul adapted very well into various circumstances he found himself. Such adaptations could easily be misunderstood. He was very much aware of himself when he exclaimed: "I have become all things to all people."

This article has followed Paul's teachings and situated them to an African family life where everyone is valued and cherished. As Africans value members of their families, Paul tried also to make his audience understand that in the church of Christ, 'there is no difference between male, and female, no difference between slave and free born, because all are children of God and members of the family of God.' As a man of faith, he lived and preached the faith he had by spreading the gospel. Above all, Paul crowned his apostolic life by dying as a martyr because of the same faith and love he had for Christ who called him and commissioned him as the apostle of the Gentiles.

\section{References}

Catechism of the Catholic Church, Pocket Edition. 1995. Dublin: Veritas Press.

Cortez, M. 2010. Theological Anthropology: A Guide for the Perplexed. New York: T \& T Clark

Diazon, B. 2010. Glimpses of Paul and his Messages. Nairobi: Pauline Publication.

Dunn, JDG. 2006. The Theology of Paul the Apostle. Michigan: WB Eerdmans Publishing Com

Fitzmyer, JA. 1980. Theology of St. Paul in Jerome Biblical Commentary. London: Geoffrey Chapman

Fleming, D. 1990. Bridge Bible Dictionary: An A to Z Bible Information. Brisbane: Bridgeway Publications

Geertz, C. 1973. Interpretation of Cultures. New York: Basic Books

Kaitholil, G. 2011. Paul, Guide to Christian Living. Mumbai: St. Paul

Kizhakke.y.il, S. 2011. The Pauline Epistles: An Exegetical Study. Mumbai: St. Paul

Kritzinger, JNJ. 2000. Exploring Theology: An Introdutory Dictionary. Pretoria: UNISA Pubs

Lapide, CA. 2008. The Personality of St. Paul. Nairobi: Pauline Publications

Lucien, L 2001. The Bible on Culture: Belonging or Dissenting? Bangalore: Theological Pubs

Magesa, L. 2010. The Challenge of African Woman, Defined Theology for the $21^{\text {st }}$ century. In Challenges and Prospects of the Church in Africa. The Theological Reflections of the $21^{\text {st }}$ century. Nairobi: Pauline Publications

McKenzie, JL. 1994. Dictionary of the Bible. London: Geoffrey Chapman

Mhlanga, E. Ncube, NJ. 2003. Research Methods and Statistics. Harare: Ultech Press Ltd.

Nwaura, PN. 2005. Women and Evangelization: A Challenge to the Church in the third Millennium, in Challenges and Prospects of the Church in Africa. Theological Reflections of the 21st Century. Nairobi: Pauline Publicationstions

Pope John Paul II 1982. The Family in the Modern World. Encyclical Letter-Familiaris Consortio. Nairobi: Pauline Publications

Pope Benedict XVI 2011. Africa's Commitment, Post Synodal Apostolic Exhortation, Africae Munus. Nairobi

Sachs, J.R. 1991. The Christian Vision of Humanity: Basic Christian Anthropology. Collegeville: Liturgical Press.

Shorter, A. 1998. African Culture an Overview. Nairobi: Pauline Publications.

Vatican II 1966. Decree on the Apostolate of the Laity No 11. Dublin: Vatican Press

Wakahiu, J. 2015. Foundations of religious Institutes and Impacts of Technology Innovation on Sisters in Africa: A Sociocultural Approach. In Voices of Courage. Nairobi Pauline Publications

Witherup, RD. 2008. Isn't Paul a Chauvinist?, in 101 Questions and Answers on Paul. Mumbai St. Paul 